\title{
PERANCANGAN TRIP CONTROL SISTEM PADA KWH METER PASCABAYAR MENGGUNAKAN SMS GATEWAY
}

\author{
Abdur Rahman Wahid ${ }^{1}$ \\ Program Studi Teknik Elektro Universitas Nurul Jadid \\ Email: abdurrahmanwahid179@gmail.com \\ Ilmi Rizki Imaduddin ${ }^{1}$ \\ Program Studi Teknik Elektro Universitas Nurul Jadid \\ Email: ilmi.eeunuja@gmail.com \\ Moh. Bachrudin ${ }^{1}$ \\ Program Studi Teknik Elektro Universitas Nurul Jadid \\ Email: udintf06@gmail.com
}

\begin{abstract}
S : PT. PLN is a State-owned enterprises (BUMN) engaged in electricity (generation, transmission, distribution). The company experiences problems every month there are arrears in electricity bill payments that have not been paid by postpaid customers. To reduce the amount of arrears, PLN officers must visit the customer's house to make a disconnection. In this study, a monitoring system for electrical energy arrears using SMS can cut off the electricity of customers who are in arrears. In designing this tool using components including Arduino Uno, relay, SIM module, step down, and SMS gateway as a communication tool with cell phones. In this test, the tool functions very well, because the maximum capacity of the relay used is 10 amperes, so this tool can be used on customers with a maximum power of 2200 VA, for testing conducted by experimenting with 2 real customer houses, data obtained from PLN for customers who are in arrears in order to disconnect and connect electricity to customers' homes that are in arrears, and reduce the amount of arrears every month so that the PLN business can survive and even develop better. This tool is inside the PLN seal, so customers cannot damage it.
\end{abstract}

\begin{abstract}
ABSTRAK: PT. PLN adalah Badan Usaha Milik Negara (BUMN) yang bergerak di bidang ketenagalistrikan (pembangkit, taransmisi, distribusi). Perusahaan mengalami kendala tiap bulannya terdapat tunggakan pembayaran rekening listrik yang belum dilunasi oleh pelanggan pascabayar. Untuk menekan jumlah tunggakan petugas PLN harus mendatangi rumah pelanggan dalam melakukan pemutusan. Pada penelitian ini menggunakan sistem monitoring tunggakan energi listrik menggunakan SMS yang dapat memutus aliran listrik pelanggan yang menunggak. Dalam Perancangan alat ini menggunakan komponen diantaranya arduino uno, relay, modul sim, step down, dan sms gateway sebagai komunikasi alat dengan ponsel. Pada pengujian ini, alat berfungsi dengan sangat baik, karena kapasitas maksimal relay yang digunakan adalah 10 ampere, sehingga alat ini bisa digunakan pada pelanggan dengan daya maksimal $2200 \mathrm{VA}$, untuk pengujian dilakukan dengan percobaan 2 rumah pelanggan real, data yang diperoleh dari PLN untuk pelanggan yang menunggak supaya melakukan pemutusan dan penyambungan aliran listrik pada rumah pelanggan yang menunggak, serta menekan jumlah tunggakan setiap bulan nya agar bisnis PLN bisa bertahan bahkan berkembang lebih baik lagi. Alat ini berada di dalam segel PLN, sehingga pelanggan tidak dapat merusaknya.
\end{abstract}

Kata kunci : Data Tunggakan Rekening Listrik, SMS Gateway, KWH Meter Pascabayar

\section{PENDAHULUAN}

$\mathrm{P}$ erusahaan PT. PLN adalah Badan Usaha Milik Negara (BUMN) yang bergerak di bidang ketenagalistrikan (pembangkit, taransmisi, distribusi).Di bagian penjualan listriknya pihak perusahaan mengalami kendala dimana setiap bulannya banyak tunggakan rekening listrik yang belum terlunasi. Perubahan dunia bisnis baik dari sisi regulasi, kompetensi, pertumbuhan ekonomi dan tuntutan pasar mendorong PT PLN (Persero) untuk melakukan perubahan strategi bisnis yang bersifat akomodatif. Dengan langkah tersebut, PLN mampu menjaga perusahaannya, bahkan bisa bertumbuh kembang di masa yang akan datang. PLN dituntut agar pencapaian target finansial mencapai kondisi yang lebih baik dari tahun-tahun sebelumnya. Namun pada kenyataannya, pihak perusahaan mengalami suatu kendala di mana tiap bulannya terdapat tunggakan pembayaran rekening listrik yang belum dilunasi oleh pelanggan pascabayar. Layanan listrik pascabayar memungkinkan pelanggan memanfaatkan listrik terlebih dahulu dalam kurun waktu tertentu (biasanya 1 bulan). Apabila melewati batas akhir pembayaran tersebut, maka pendapatan yang seharusnya diterima PLN berubah menjadi piutang penjualan tenaga listrik, faktor penyebabnya antara lain pelanggan malas, lupa, sengaja tidak membayar maupun karena kondisi kesulitan ekonomi. Sebagai upaya untuk mencapai target kinerja yang telah ditetapkan, maka PLN memandang perlu untuk melakukan penajaman strategi bisnis agar dapat meningkatkan target finansial sekaligus meningkatkan pelayanan kepada pelanggan [1]. Langkah perusahaan untuk menekan jumlah tunggakan listrik pelanggan pascabayar yaitu dengan melakukan pemutusan aliran listrik sementara agar pelanggan menyadari kewajibannya untuk melunasi tunggakan tersebut. Selama ini pemutusan dilakukan menggunakan stiker dan atau segel, yang tingkat efektivitasnya kurang memberikan keuntungan bagi perusahaan karena pelanggan masih leluasa menyalakan aliran listrik

${ }^{1}$ Universitas Nurul Jadid, Karanganyar, Kecamatan Paiton, Kabupaten Probolinggo, Jawa Timur 67292 
dengan jalan merusak segel atau stiker yang terpasang pada APP (Alat Pembatas dan Pengukur) dan memindah swith Miniature Circuit Breaker (MCB) pada posisi (ON). Karena kondisi inilah petugas melakukan pemutusan dengan cara melepas sambungan pada terminal dalam kotak APP, Justru hal ini menimbulkan dampak negatif berupa banyaknya kotak APP tidak tersegel yang berarti meningkatkan resiko pencurian aliran listrik [2].

Pada Kilowatt hour $(\mathrm{KWH})$ meter prabayar, teknologi perhitungan konsumsi daya listrik yang digunakan oleh pelanggan yaitu dengan mengubah sinyal analog tegangan dan arus yang terukur menjadi sinyal digital dengan mengambil sample dan dilengkapi dengan sistem pemutus sendiri sehingga pelanggan tidak bisa menggunakan listrik jika token atau pulsa nya sudah habis. Sistem yang digunakan KWH meter pascabayar ini masih manual serta tidak ada sistem pemutusnya, dan pencatatan pemakaian daya dalam 1 bulan juga secara manual yaitu pihak PLN mendatangi satu persatu rumah pelanggan yang menggunakan KWH meter pascabayar [3].

Dari permasalahan yang terjadi yaitu banyak nya APP tidak tersegel yang mengakibatkan meningkatkan resiko pencurian aliran listrik, maka penulis akan memberikan solusi dengan merancang sebuah alat yang bisa memutus dan menyambung aliran listrik tanpa harus mendatangi rumah pelanggan. Dimana sistem komonikasinya menggunakan SMS Gateway yang lebih murah untuk biaya infrastruktur terhadap PLN dan lebih efisien dibanding dengan menggunakan internet of thing (IOT).

Berdasarkan latar belakang tersebut penulis akan merancang sebuah alat yang berjudul, "Perancangan Trip Control Sistem Pada KWH Meter Pascabaya Menggunakan SMS Gateway" sebagai tugas akhir yang memiliki kelebihan tidak mudah dirusak oleh pelanggan serta dapat digunakan secara berulang-ulang untuk mengganti stiker dan atau segel.

\section{METODOLOGI}

Pada bab ini alur penelitian dibahas mengenai perancangan "Perancangan Trip Control Sistem Pada Kwh Meter Pascabayar Menggunakan Sms Gateway". Perancangan mekanik, (hardware), perangkat lunak (software), dan peralatan penunjang yang dibahas pada alat ini meliputi:

a. Perancangan keseluruhan alat

b. Perancangan hardware

- Perancangan arduino

- Perancangan modul sim

- Perancangan relay

c. Perancngan software

d. Perancangan peralatan penunjang

- Daya masukan dari PLN

- Data tunggakan pelanggan

- Handphone

\section{a. Perancangan Keseluruhan Alat}

Pada tugas akhir ini saya mengunakan kwh meter PLN sebagai beban untuk melakukan percobaan pada pelanggan yang menunggak. Suplai utama pada alat ini adalah dari PLN satu phase, jika PLN mengalami gangguan maka, controller akan secara otomatis menyimpan data terakhir relay. 


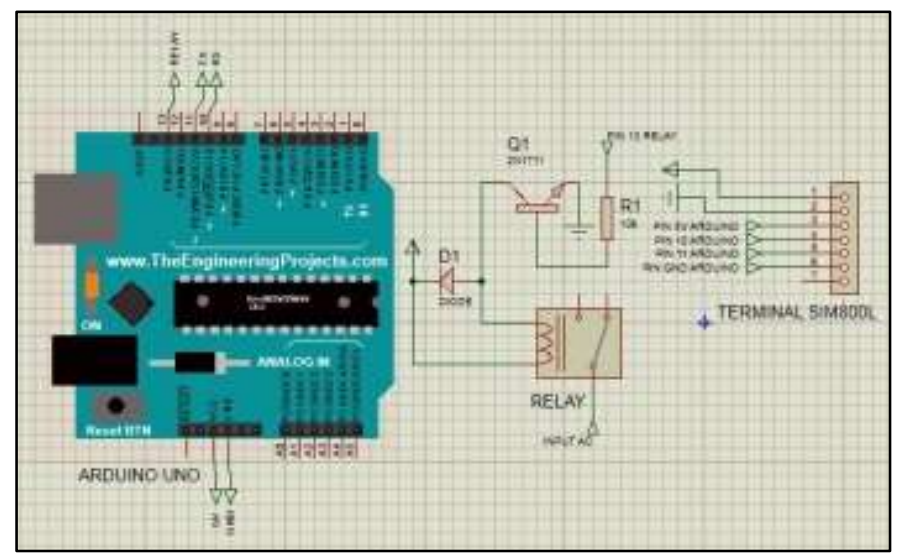

Gambar 1. Skematik Rangkaian Sistem Pemutus

b. Perancangan Hardware

Perancangan hardware pada tugas akhir ini terdiri dari perancangan arduino, perancangan modul sim, perancangan relay, perancangan DC to DC converter

1) Perancangan Arduino

Menggunakan microcontroller Atmega 168 untuk menyimpan program utama. pin yang digunakan adalah pin 10,11, 13 pada arduino untuk komunikasi terhadap modul sim dan relay.

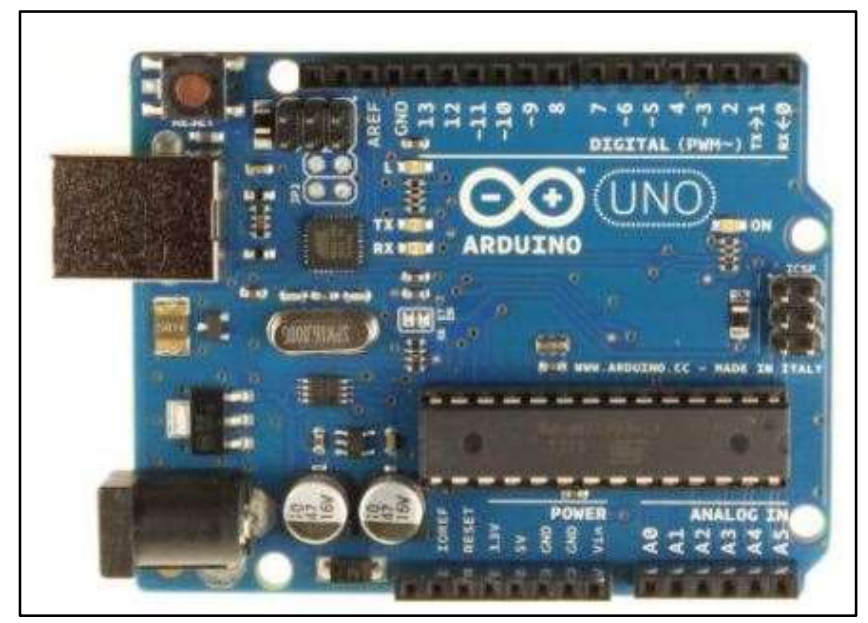

Gambar 2. Arduino Uno

Arduino Uno dilengkapi dengan flash memori sebesar 16 kbyte dan dapat digunakan untuk menyimpan kode program utama. Flash memori ini sudah terpakai 2 kbyte untuk program boatloader sedangkan Atmega328 dilengkapi dengan flash memori sebesar 32 kbyte dan dikurangi sebesar 2 kbyte untuk boatloader [4].

- Tabel 1. Spesifikasi Microcontroller.

\begin{tabular}{|l|l|}
\hline Microcontroller & Atmel ATmega168 or ATmega328 \\
\hline $\begin{array}{l}\text { Operating Voltage (logic } \\
\text { level) }\end{array}$ & $5 \mathrm{~V}$ \\
\hline $\begin{array}{c}\text { Input Voltage } \\
\text { (recommended) }\end{array}$ & $7-12 \mathrm{~V}$ \\
\hline Input Voltage (limits) & $6-20 \mathrm{~V}$ \\
\hline Digital I/O Pins & 14 (of which 6 provide PWM output) \\
\hline Analog Input Pins & 8 \\
\hline
\end{tabular}


Perancangan Trip Control Sistem pada Kwh Meter Pascabayar Menggunakan Sms Gateway

\begin{tabular}{|l|l|}
\hline DC Current per I/O Pin & $40 \mathrm{Ma}$ \\
\hline Flash Memory & $\begin{array}{l}\text { 16 KB (ATmega168) or 32 KB } \\
\text { (ATmega328) of which 2 KB used } \\
\text { by bootloader }\end{array}$ \\
\hline SRAM & $\begin{array}{l}\text { 1 KB (ATmega168) or 2 KB } \\
\text { (ATmega328) }\end{array}$ \\
\hline EEPROM & $\begin{array}{l}512 \text { bytes (ATmega168) or 1 KB } \\
\text { (ATmega328) }\end{array}$ \\
\hline Clock Speed & $16 \mathrm{MHz}$ \\
\hline Dimensions & $0.73^{\prime \prime} \mathrm{x} 1.70^{\prime \prime}$ \\
\hline Length & $45 \mathrm{~mm}$ \\
\hline Width & $18 \mathrm{~mm}$ \\
\hline Weigth & $5 \mathrm{~g}$ \\
\hline
\end{tabular}

2) Perancangan Modul SIM

SIM 8001 merupakan suatu modul General Service for Mobile (GSM) yang dapat mengakses General Packet Radio Service (GPRS), yang bekerja pada frekuensi GSM850MHz, EGSM900MHz, DCS1800MHz dan PCS1900MHz. Pin yang terhubung ke sistem arduino uno diantaranya pin vdd terhubung ke pin 5v arduino, pin gnd terhubung ke pin arduino gnd, pin txd terhubung ke pin 10 arduino, pin rxd terhubung ke pin 11 arduino. [5].

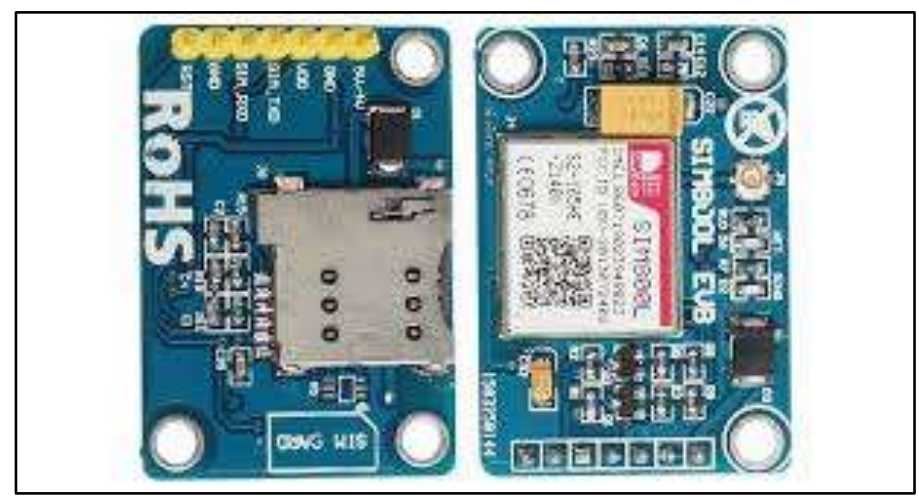

- Gambar 3. SIM 800L V2.

Modul GSM SIM800L V2 memiliki 7 pin dimana setiap masing-masing pin memiliki fungsi yang berbeda. Adapun Datasheet dari pin tersebut sebagai berikut :

Tabel 2. Fungsi Setiap Pin Modul GSM.

\begin{tabular}{|c|c|l|}
\hline NO & NAMA & \multicolumn{1}{|c|}{ KETERANGAN } \\
\hline 1 & GND & Ground \\
\hline 2 & TXD & Transmit Data \\
\hline 3 & RXD & Receive Data \\
\hline 4 & RST & Reset \\
\hline 5 & VDD & 5 VDC Input Supply (Typical) \\
\hline 6 & VCC & 5 VDC Input Supply (Typical) \\
\hline
\end{tabular}

3) Perancangan Relay

Relay adalah komponen elektronika yang digerakkan oleh arus listrik, tuas saklar dengan lilitan kawat pada batang besi (coil), prinsip kerja jika coil mendapatkan tegangan maka tuas yang semula Normally Close (NC) menjadi Normally Open (NO). Proses ini terjadi karena relay memanfaatkan medan magnet sebagai media penggeraknya. Susunannya terdiri dari kumparan kawat yang dililit pada inti besi. Bila kumparan ini di aliri arus akan menimbulkan medan magnet digunakan sebagai pengungkit tuas mekanisme sakelar magnet [6]. 


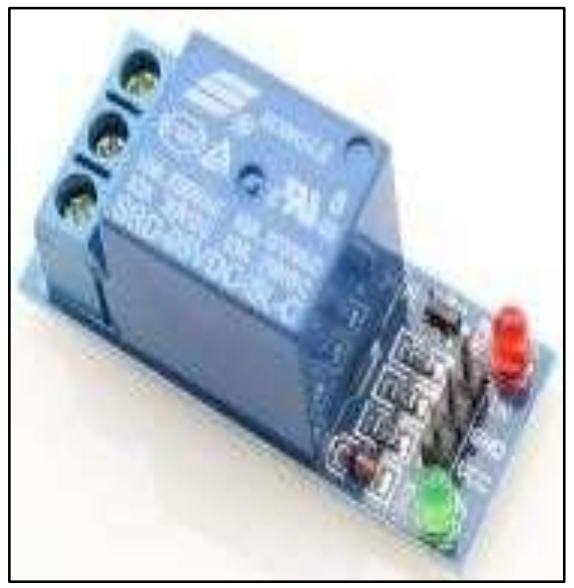

Gambar 4. Modul Relay

Relay ini memerlukan arus sebesar sekurang-kurangnya $15-20 \mathrm{~mA}$ untuk mengontrol channel. Disertai dengan relay high-current sehingga dapat menghubungkan perangkat dengan tegangan AC250V 10A. Alasan relay ini digunakan adalah karena arduino menggunakan tegangan kerja masing masing pin input output adalah $0 / 5$ volt.

Pada dasarnya, Relay terdiri dari 4 komponen dasar yaitu :

a. Electromagnet (Coil)

Merupakan lilitan yang terbentuk dari kawat tembaga dengan lapisan email yang fungsinya sebagai pembentuk medan magnet ketika mendapatkan tegangan listrik yang sesuai dengan tegangan kerja relay.

b. Armature

Merupakan material atau lempengan logam yang berfungsi sebagai tuas kontak yang bergerak merubah posisi kontak tergantung dari sifat magnet dari komponen inti besi yang mempengaruhinya.

c. Switch Contact Point (Saklar)

Merupakan bagian dari relay yang berfungsi sebagai kontak output relay. Switch kontak ini terdapat 2 kondisi yaitu NO (normally open) dan NC (normally close). Normally open maksudnya adalah bahwa kontak relay secara normal saat lilitan A1 dan A2 belum mendapat tegangan adalah kontak terbuka. Sedangkan normally close maksudnya adalah bahwa kontak relay secara normal saat lilitan A1 dan A2 belum mendapat tegangan adalah kontak tertutup.

d. Spring

Spring atau per merupakan bagian dari relay yang berfungsi mengembalikan posisi switch contact poin relay saat lilitan coil A1 dan A2 tidak bertegangan.

\section{c. Perancangan Software}

Perancangan Perangkat lunak (Software) merupakan langkah membuat program untuk menjalankan alat sesuai dengan sistem pemutusan. Software yang digunakan adalah Arduino Ide yang merupakan compiler bawaaan pada Arduino. Hal yang perlu di atur dalam pembuatan program alat ini adalah pin I/O yang akan digunakan serta pin RX TX untuk komunikasi dengan GSM. 


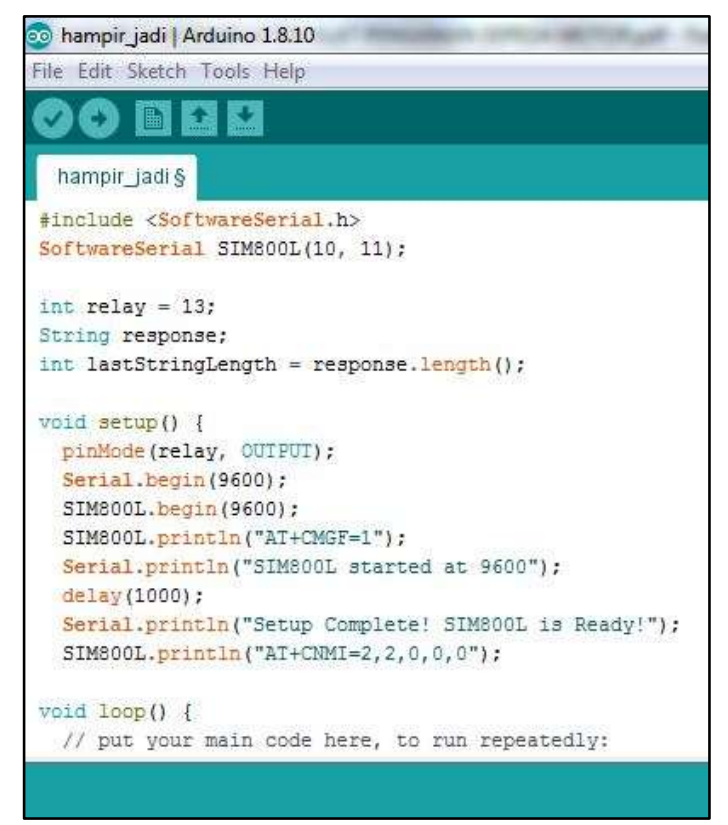

Gambar 6. Listning Program

d. Perancangan Peralatan Penunjang

Dalam sub bab ini akan dijelaskan mengenai peralatan yang digunakan sebagai peralatan penunjang pada sistem pemutus.

1) Daya dari PLN

Daya yang digunakan sebagai suplai utama pada alat ini adalah daya dari PLN. Tegangan suplai untuk sistem pemutus di ambil dari output kwh meter 1 phase dengan daya maksimal 2200.

2) Data tunggakan pelanggan

Data tunggakan di perlukan untuk melakukan percobaan alat yang telah di rancang agar bisa mengetahui alat sudah bekerja dengan baik sesuai perancangan. Data tunggakan ini diperoleh dari PLN sesuai dengan kondisi real dilapangan.

Tabel 3. Data Tunggakan Pelanggan

\begin{tabular}{|c|c|c|c|c|}
\hline NO & Nama & ID Pelanggan & Daya & Tunggakan \\
\hline 1 & Tutik B Asmad & 513570600387 & 900 & 2 bulan \\
\hline 2 & Tohir & 513570096966 & 900 & 2 bulan \\
\hline 3 & H Rasidi & 513570192248 & 1300 & 2 bulan \\
\hline 4 & Atima & 513570695754 & 900 & 2 bulan \\
\hline 5 & Kasmudin & 513570644150 & 900 & 2 bulan \\
\hline 6 & Latip Nurullah & 513570286955 & 450 & 2 bulan \\
\hline 7 & Nurhasanah & 513570613980 & 900 & 2 bulan \\
\hline 8 & Hafidz Supriyadi & 513570189706 & 900 & 2 bulan \\
\hline 9 & Moh. Hasan & 513570639160 & 900 & 2 bulan \\
\hline 10 & Udin P Daryo & 513570511891 & 900 & 2 bulan \\
\hline
\end{tabular}

\section{3) Handphone}

Hanpdhone digunakan untuk mengirimkan sms pada modul sim, perintah yang digunakan berupa ON dan OFF untuk mengaktifkan kontak coil relay.

\section{HASIL DAN PEMBAHASAN}

Hasil pengujian keseluruhan dari sistem pemutus menggunakan sms gateway bertujuan untuk menekan jumlah tunggakan pelanggan pascabayar. Berikut beberapa pengujian yang akan dilakukan terhadap sistem pemutus aliran listrik pada rumah pelanggan yang menunggak menggunakan sms gateway. 


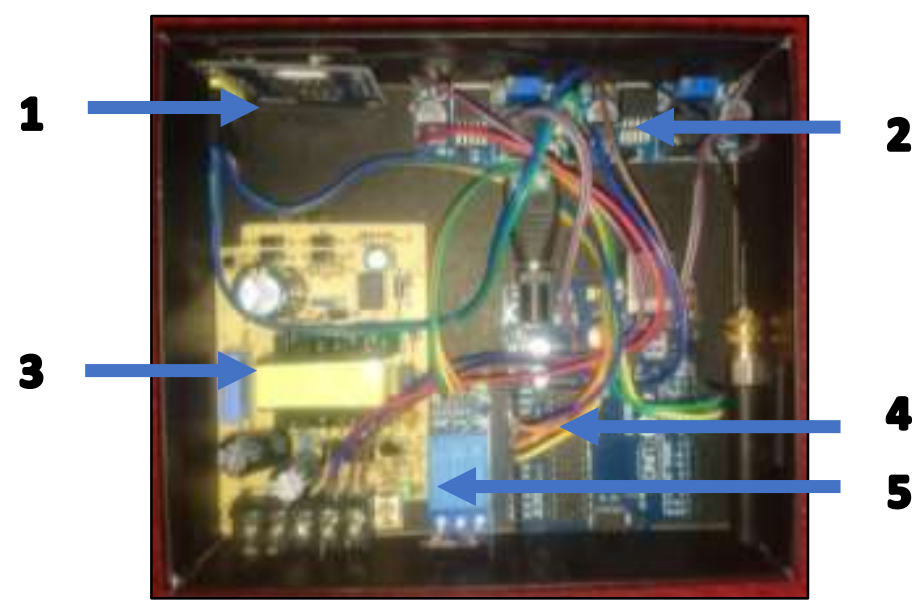

Keterangan :

Gambar 7. Hasil Alat Tampak Dalam

1. SIM 800L sebagai komunikasi alat dengan ponsel

2. Step down sebagai penurun tegangan

3. Power supply sebagai supply untuk alat

4. Controller Untuk pengolah data

5. Relay sebagai pemutus dan penyambung aliran listrik

Pada tugas akhir ini ada tiga pengujian yaitu Pengujian kirim pesan singkat berupa karakter OFF dan karakter ON, pengujian respon modul sim terhadap pesan singkat berupa karakter OFF dan karakter ON, serta pengujian pembacaan kondisi terakhir relay jika terjadi gangguan jaringan PLN. Pengujian tersebut perlu dilakukan untuk mengetahui program yang tertanam pada controller sudah berfungsi dengan baik atau tidak.

1. Hasil Pengujian Kirim Pesan Dengan Karakter OFF dan ON

Pengujian dan pembahasan ini dilakukan bertujuan untuk mengetahui apakah perintah untuk melakukan pemutusan pemakaian energi listrik pada pelanggan yang menunggak yang akan dikirim menggunakan pesan singkat dapat diterima dengan baik sesuai perencanaan.

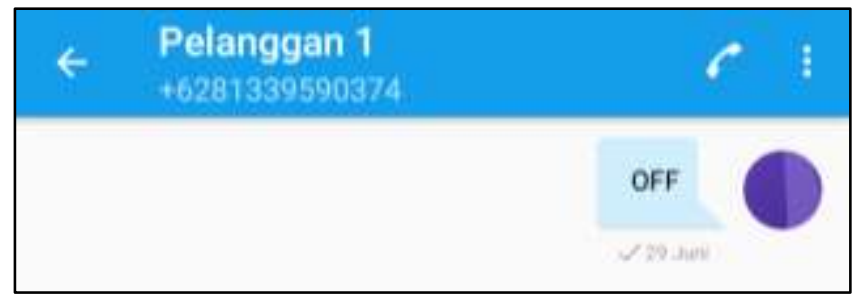

Gambar 8. Kirim Pesan OFF

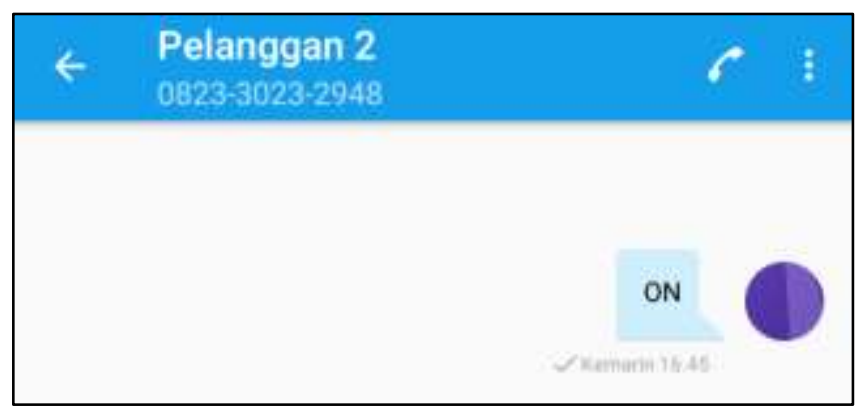

Gambar 9. Kirim Pesan ON

Dari hasil pengujian diatas, karakter yang dikirim pada nomor SIM card yang tertanam pada alat berupa pesan singkat ON dan OFF berhasil terkirim ditandai dengan tanda centang di bawah pesan yang 
menandakan bahwa SIM card yang tertanam pada alat mendapatkan signal sehingga bisa menerima pesan yang dikirim operator PLN untuk melakukan pemutusan dan penyambungan aliran listrik pada rumah pelanggan.

2. Hasil Pengujian Respon Modul SIM Terhadap Karakter OFF dan ON

Pengujian dan pembahasan ini dilakukan bertujuan untuk mengetahui apakah modul sim merespon terhadap pesan singkat yang dikirimkan berupa karakter "OFF" agar operator PLN dapat mengetahui kondisi dirumah pelanggan yang menunggak setelah mengirimkan pesan singkat tersebut.

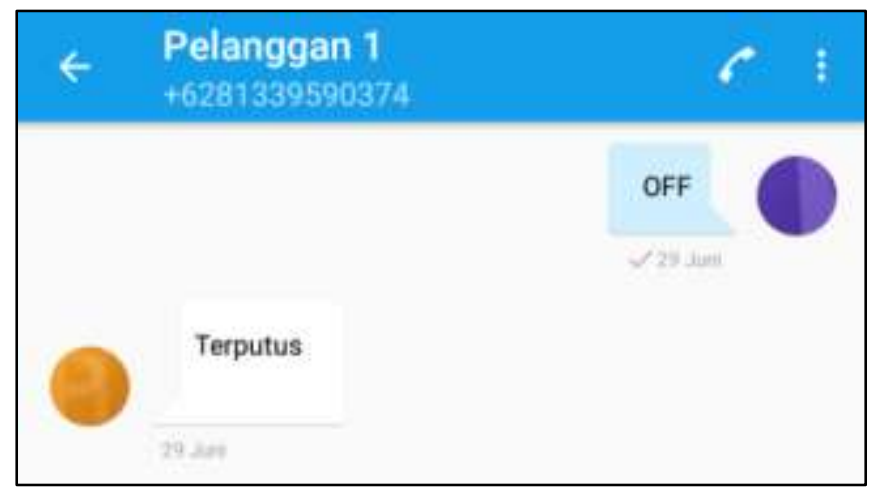

- Gambar 10. Respon Modul SIM Karakter OFF

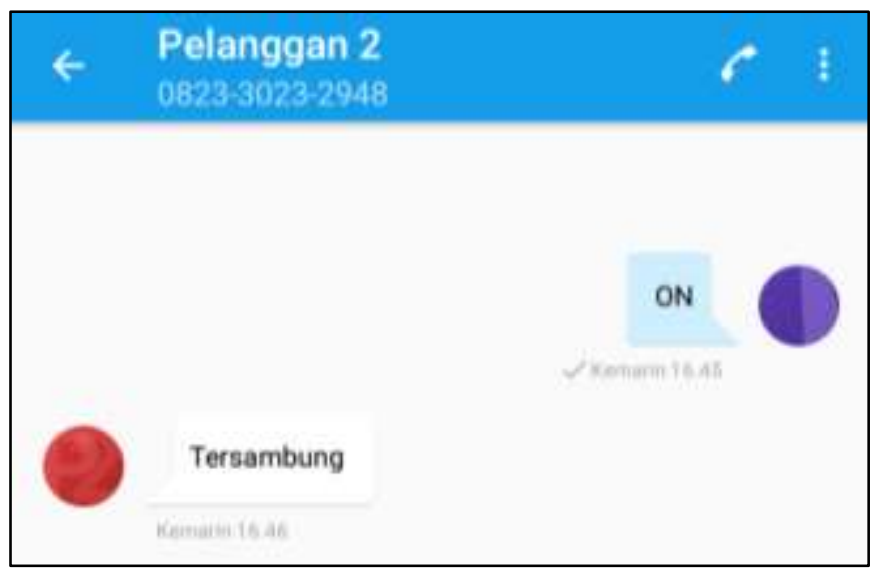

Gambar 11. Respon Modul SIM Karakter ON

Dari hasil pengujian diatas, dapat dilihat bahwa modul sim merespon terhadap pesan singkat yang dikirim oleh operator PLN, sehingga operator PLN dapat mengetahui kondisi real dilapangan. Pengujian ini perlu dilakukan agar operator PLN dapat memastikan bahwa perintah untuk melakukan pemutusan dan penyambungan aliran listrik pelanggan tersampaikan dengan baik pada alat dan modul sim akan memberikan feedback bahwa telah melakukan tindakan pemutusan atau penyambungan aliran listrik pelanggan.

3. Hasil Pengujian Pembacaan EEPROM Pada Kondisi Terakhir OFF

Pengujian ini dilakukan untuk mengetahui apakah controller menyimpan kondisi terakhir relay " OFF" jika terjadi pemadaman listrik, agar pada saat listrik normal kembali, posisi relay tetap seperti awal sebelum listrik PLN mati agar operator bisa memonitoring jumlah tunggakan yang sudah dilakukan pemutusan. 


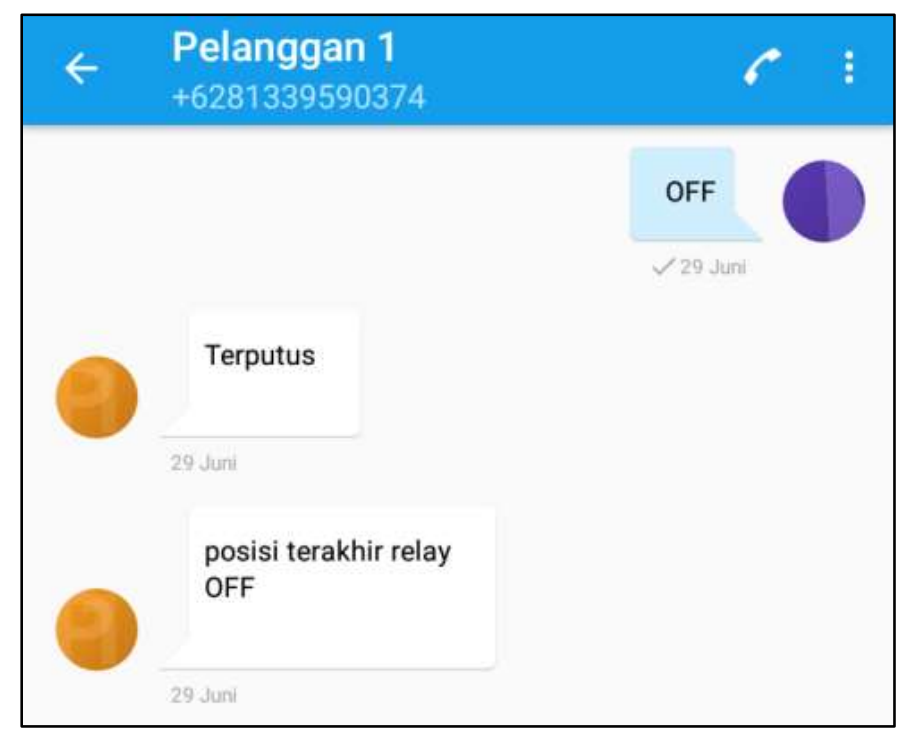

Gambar 12. Pembacaan Kondisi Terakhir OFF

Dari hasil pengujian diatas, dapat dilihat bahwa modul sim yang tertanam pada alat mengirimkan pesan kepada operator PLN berupa kondisi terakhir relay dirumah pelanggan. Informasi ini bertujuan agar operator PLN mempunyai rekap data terhadap rumah pelanggan yang telah dilakukan pemutusan. Pesan ini hanya akan diterima operator jika jaringan PLN mengalami gangguan.

\section{Hasil Pengujian Pembacaan EEPROM Pada Kondisi Terakhir ON}

Pengujian ini dilakukan untuk mengetahui apakah controller menyimpan kondisi terakhir relay "ON" jika terjadi pemadaman listrik, agar pada saat listrik normal kembali, posisi relay tetap seperti awal sebelum listrik PLN mati agar operator bisa memonitoring jumlah tunggakan yang sudah dilakukan penyambungan kembali aliran listrik.

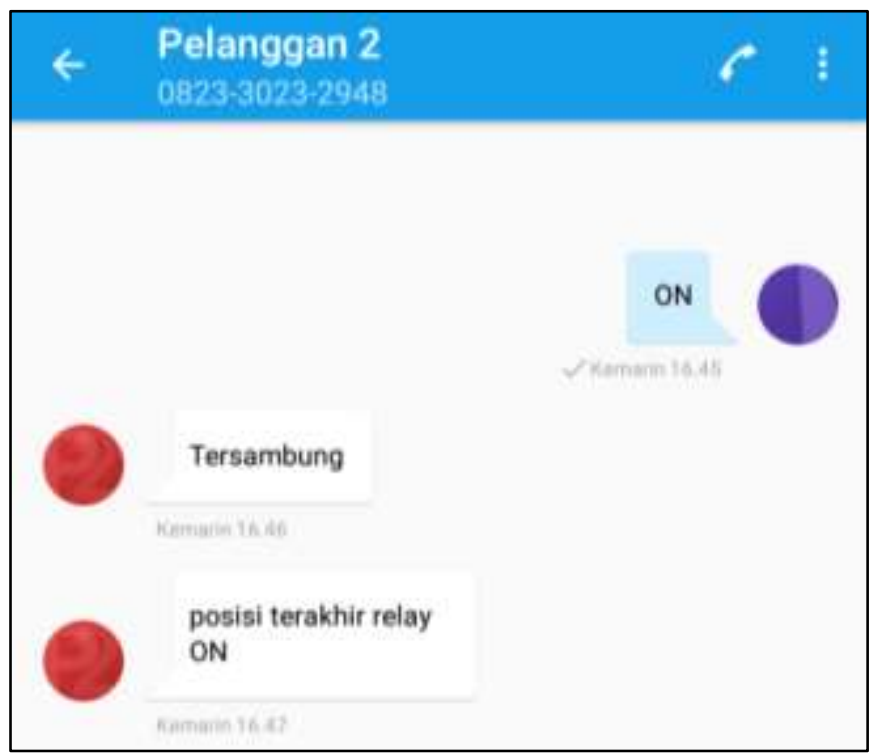

Gambar 13. Pembacaan Kondisi Terakhir ON

Dari hasil pengujian diatas, dapat dilihat bahwa modul sim yang tertanam pada alat mengirimkan pesan kepada operator PLN berupa kondisi terakhir relay dirumah pelanggan. Informasi ini bertujuan agar operator PLN mempunyai rekap data terhadap rumah pelanggan yang telah dilakukan penormalan kembali aliran listrik. Pesan ini hanya akan diterima operator jika jaringan PLN mengalami gangguan.

Pengujian pembacaan EEPROM diatas perlu dilakukan supaya jika terjadi gangguan controller akan menyimpan kondisi terakhir relay yang tertanam pada alat. Sehingga operator PLN tidak perlu melakukan pemutusan dan penyambungkan aliran listrik pelanggan lagi jika listrik PLN normal kembali. Karena suplai dari alat murni dari listrik PLN tanpa ada backup dari baterai sehingga jika jaringan PLN mengalami 
gangguan alat tidak akan medapat suplai, otomatis controller yang tertanam pada alat akan reset ke program awal.

5. Hasil Pengujian Alat Pada Rumah Pelanggan Real

Pengujian ini perlu dilakukan untuk mengetahui apakah alat bisa bekerja dengan baik sesuai perencanaan jika di hubungkan dengan beban langsung. Agar pada saat alat ini dipasang dirumah pelanggan, alat ini mampu melakukan pemutusan dan penyambungan aliran listrik.

Tabel 4. Pengujian Alat Pada Rumah Pelanggan Real.

\begin{tabular}{|c|c|c|c|c|c|}
\hline NO & ID Pelanggan & ID SIM & Terkirim & $\begin{array}{c}\text { Respon } \\
\text { Modul } \\
\text { SIM }\end{array}$ & $\begin{array}{c}\text { Pembacaan } \\
\text { EEPROM }\end{array}$ \\
\hline 1 & 3217501972 & +6281339590374 & Ya & Ya & Ya \\
\hline 2 & 513570614743 & +6282330232948 & Ya & Ya & Ya \\
\hline
\end{tabular}

Pengujian alat ini diawasi oleh operator PLN karena melibatkan rumah pelanggan. Pada pengujian ini, alat berfungsi dengan sangat baik dan dapat dipakai berulang-ulang, menggantikan segel atau stiker yang hanya satu kali pakai. Pemasangan / pelepasan mudah, cepat dan tidak merusak segel APP yang ada, serta dapat di implementasikan secara luas seluruh unit PLN dalam rangka menekan angka tunggakan. Karena kapasitas maksimal relay yang digunakan adalah 10 ampere, sehingga alat ini bisa digunakan pada pelanggan dengan daya maksimal $2200 \mathrm{VA}$, pengujian ini dilakukan dengan percobaan 2 rumah pelanggan real. Pengujian ini perlu dilakukan agar jika alat ini diimplementasikan oleh pihak PLN alat ini mampu dan sudah dilakukan percobaan pada rumah pelanggan real. Data pelaggan menunggak yang diperoleh dari PLN rata-rata selama 2 bulan, maka dari itu alat ini sangat dibutuhkan untuk melakukan pemutusan dan penyambungan aliran listrik pada rumah pelanggan yang menunggak, serta dapat menekan jumlah tunggakan setiap bulan nya agar bisnis PLN bisa bertahan bahkan berkembang lebih baik lagi. Alat ini berada di dalam segel PLN, sehinnga pelanggan tidak dapat merusaknya.

\section{KESIMPULAN}

Setelah melakukan perancangan, perencanaan, pembuatan, pengujian dan pembahasan serta hasil perancangan trip control sistem pada $\mathrm{KwH}$ meter pascabayar menggunakan sms gateway,maka diambil kesimpulan sebagai berikut:

1. Alat sistem pemutus aliran listrik menggunakan sms gateway berbasis arduino uno telah dapat dirancang dan sistem notifikasi untuk pemutus dan penyambungan aliran listrik pada pelanggan yang menunggak serta pembacaan kondisi terakhir relay dapat dilakukan melaui sms.

2. Alat dapat dipakai berulang-ulang, pemasangan / pelepasan mudah, cepat dan tidak merusak segel APP yang ada, serta dapat di implementasikan secara luas seluruh unit PLN dalam rangka menekan angka tunggakan.

3. Alat berada didalam segel PLN sehingga pelanggan tidak dapat merusaknya.

\section{DAFTAR PUSTAKA}

[1] M. N. Fitri, "Perbandingan Pendapatan Jasa Listrik Pascabayar Pada PT.PLN (Persero) Rayon Rungkut” STIE Perbanas, 2018.

[2] H. Y. P, M. Aliyuddin, and E. Prasejo, "Solusi Pelanggan Nunggak Dengan Android Berbasis Mikrocontroller" pp. 1-28, 2019.

[3] D. Gunawan, Y. Shalahuddin, and D. Erwanto, "Studi Komparasi Kwh Meter Pascabayar Dengan Kwh Meter Prabayar Tentang Akurasi Pengukuran Terhadap Tarif Listrik Yang BervariasI" Setrum Sist. Kendali-Tenaga-Elektronika-Telekomunikasi-Komputer, vol. 7, pp. 158-168, 2018.

[4] Farnell, “Arduino Uno Datasheet," Datasheets, pp. 1-4, 2013.

[5] SIMCom, "SIM800 Series AT Command Manual," SIM800 Series AT Command Manual, 2015. 
[6] B. Santoso, "Rancang Bangun Prototipe Sistem Monitoring Pengontrolan Distribusi Pada Pltmh Gunung Sawur Dengan Sistem Scada” Universitas Jember, 2017. 